\title{
Sustainable Development Agriculture in the Republic of Kazakhstan
}

\author{
Aigul Tokbergenova*, Lazzat Kiyassova, Shnar Kairova \\ Al-Farabi Kazakh National University, Department of Geography, Land Management and Cadastre, \\ 050040 Almaty, Republic of Kazakhstan
}

Received:14 June 2017

Accepted: 14 October 2017

\begin{abstract}
The article deals with the problems of sustainable development of agricultural sector in the Republic of Kazakhstan; the analysis of the development of the agro-industrial complex; the problems of ensuring the sustainability of agriculture are emphasized and analyzed. Agriculture has historically been the backbone of Kazakhstan's economy. This is mainly due to the difference in natural and climatic conditions and the presence of vast areas of desert and semi-desert pasture land. In the modern period, the agrarian sector of the country is forced to function in the conditions of severe degradation of agricultural lands, the increase of environmental and water problems, the use of physically and morally outdated equipment and technology. Environmental problems related with agricultural activities include: depletion and degradation of soil due to past state programs, erosion, secondary salinization and flooding; lack of water; degradation of pastures caused by overgrazing and incomplete use/abandonment of more remote pastures; soil contamination with chemicals; and reduced biodiversity, for example, water biodiversity of the Aral Sea. In connection with the normative of inefficient use of agricultural land fixed in Kazakhstan, the necessity in the improvement of the mechanisms for managing the turnover of agricultural land requires the study of positive foreign practices in regulating land relations.
\end{abstract}

Keywords: sustainable development, rural areas, agricultural sector, Republic of Kazakhstan, profitability of agricultural products

\section{Introduction}

An efficient agricultural sector is the basis of material and social well-being of society, and sustainable development is impossible without it. The problem of achieving sustainable production of agricultural products is one of the most important tasks in modern society.
From the theoretical point of view, to meet the needs of society, sustainability must ensure a steady increase in the production of agricultural products. But in reality this is not always possible because of extreme deviations of weather conditions, as well as irrational use of the resource potential, non-observance of the timing and technology of cultivation of agricultural crops, losses during harvesting, transportation, and storage of products.

Climatic conditions in the republic are favorable for crops. For example, in the north of the country, spring

*e-mail: tokbergenova.aygul@kaznu.kz 
wheat, oats, barley, and other cereals are grown. In terms of grain production, Kazakhstan ranks third in the CIS after Russia and Ukraine. The climatic conditions of the country also allow for the development of vegetable growing, melon growing, and cultivating such technical crops as sunflower, flax, tobacco, etc. In the south of the country, cotton, sugar beets, yellow tobacco, rice, orchards, and vineyards give high yields.

Rational development of the agricultural sector of the economy is one of the fundamental achievements of economically developed countries. In developing and post-Soviet countries, this problem has not been completely solved.

Sustainable development of agricultural production is understood as a system of management that ensures constant and sufficient supply of the population of urbanized territories with food and industry with raw materials, provided that efficient economic activity does not harm the natural environment by applying advanced environmentally oriented technologies [1-3].

A more detailed definition of sustainable agriculture is given by the U.S. Department of Agriculture in programs of the USDA's Sustainable Agriculture Research and Education (SARE) and Cooperative State Research, Education, and Extension Service (CSREES).

Sustainable agriculture is considered to be a system that creates and controls natural biological cycles; protects and restores soil fertility and natural resources; optimizes the use of resources in the enterprise; reduces the use of non-renewable resources; provides a steady income to the rural population; applies the opportunities of domestic and public farming; and minimizes adverse effects on health, security, nature, water quality, and the environment [4-7].

\section{Materials and Methods}

The period of study covers the years of independence since 1991. The informational basis of the work was based on the statistics and stock materials and data on sustainable development of the agricultural sector in the Republic of Kazakhstan Statistics Agency (stat.gov. $\mathrm{kz}$ ), the Committee of Land Resources Management, the Ministry of Agriculture of the Republic of Kazakhstan, as well as monographs, books, and scientific publications of scientists.

The study of the problem of sustainable development of agriculture in the Republic of Kazakhstan was based on the following methods: comparative-geographical, cartographical, spatial analysis, economic and statistical analysis, and GIS methods.

For comparative analysis of data in dynamics we considered agricultural lands by the oblasts for 1991, 2005, 2010, 2014 and 2015, plus dynamics of gross agricultural products for 1995, 2000, 2005, 2010, and 2015. Thus the changes in dynamics over a 5-year period are discussed. The article also presents an interim analysis of data on population of rural areas for 2010-2015 [8-9].

The spatial analysis of lands of agricultural land by the oblasts is based on distribution of structure of the land fund for 1 November 2015 [9]. Also, specific weight of gross agricultural products is based in branches of crop production and livestock production.

Based on economic and statistical analysis we:

- Analyzed the development of the agro-industrial complex of the Republic of Kazakhstan.

- Looked at analysis-based indicators of agriculture in Kazakhstan.

- Evaluated the export potential of agricultural production.

- Investigated problems and prospects of sustainable development of agrarian and industrial complex of Kazakhstan.

During the processing of the data were used software packages of ArcGIS and Excel spreads, made maps of the agricultural lands of the Republic of Kazakhstan, and gross agricultural products of Kazakhstan (scale $1: 3,000,000)[9,16]$.

\section{Results and Discussion}

Use of Agricultural Land in the Agricultural Sector

Land is the most important condition for the existence of human society. In different sectors of the economy, the role of land is not the same. In agriculture, land becomes the main means of production; it functions simultaneously as an object of labor and as a means of labor.

The area of agricultural land in the structure of the land fund of Kazakhstan is 100.8 million hectares, or $38.6 \%$ of used land. Their share in the land fund of the oblasts ranges from $70-75 \%$ (North Kazakhstan, Akmola) to $10-20 \%$ (Kyzylorda, Atyrau). This is mainly due to the difference in natural and climatic conditions and the presence of vast areas of desert and semi-desert pasture land.

\section{The Dynamics of the Area of Agricultural Land by Oblasts}

For the period of reforming agricultural enterprises in 1991-2005, the area of agricultural land in the country decreased by 136.2 million hectares, but then the area of this category of land increased annually and its total increase from 2005 to 2015 was 18.6 million hectares.

The most valuable land for agricultural purposes (97.4\% of arable land) is in the category of agricultural land, including $91.1 \%$ of irrigated land, $56.2 \%$ of perennials, $51.7 \%$ of fallow land, and $42.4 \%$ of hayfields, of which $33.6 \%$ is ameliorated land and $52.0 \%$ estuary irrigation. 
In the structure of agricultural lands arable land is $9 \%$, perennial plantations $0 \%$, fallow land $2 \%$, hayfields $2 \%$, grassland $69 \%$, and non-agricultural land $18 \%$.

The main areas of arable land are in the grain oblasts: Kostanay (6.0 million hectares), Akmola (5.6 million hectares), and North Kazakhstan (4.8 million hectares). The largest areas of grassland are concentrated in the oblasts located in desert and semi-desert zones, namely in Karaganda (12.2 million hectares), East Kazakhstan (8.3 million hectares), Aktobe (8.5 million hectares), and Almaty (7.1 million hectares).

The largest areas of fallow land are in Akmola (442.2 thousand ha), West Kazakhstan (455.5 thousand ha), Pavlodar (492.7 thousand ha), Aktobe (447.0 thousand ha), and Karaganda (303.2 thousand hectares).

More than $50 \%$ of hayfields are in four oblasts: East Kazakhstan (455.5 thousand hectares), West Kazakhstan (352.2 thousand hectares), Karaganda (224.8 thousand hectares), and Almaty (209.6 thousand hectares).

The share of agricultural land in the republic is $38.6 \%$, varying by oblasts from $73.7 \%$ (North Kazakhstan) and $72.2 \%$ (Akmola), up to $10.1 \%$ (Kyzylorda) and 21.3\% (Atyrau).

The share of agricultural land in the land funds of the oblasts is shown in Fig 1. [9-11].
Stages of the Development of the Agro-Industrial Complex in Kazakhstan

Agriculture has historically been the backbone of Kazakhstan's economy. Kazakhs were nomads and the production of livestock products remains important. After the 1860s, when Central Asia was annexed to the Russian Empire, cotton became the key crop in the irrigated oblasts of the Syr Darya River in southern Kazakhstan. Mixed production was in the dryfarming land of the southeastern part of the country. According to the program of the development of virgin and fallow lands in the 1950s and 1960s, they began to develop grain farming in the steppe lands of northern Kazakhstan. However, as in neighboring Siberia, changeable climate led to fluctuations in productivity, and about $30 \%$ of the soil on some lands was unsuitable for long-term cultivation, according to the World Bank (1992) [12].

Since declaring independence, Kazakhstan, like other post-Soviet states, began to modernize and reform all sectors of the economy. This period was the beginning of the formation of a new stage in the development of agriculture; it was characterized by the development of new forms of ownership and business

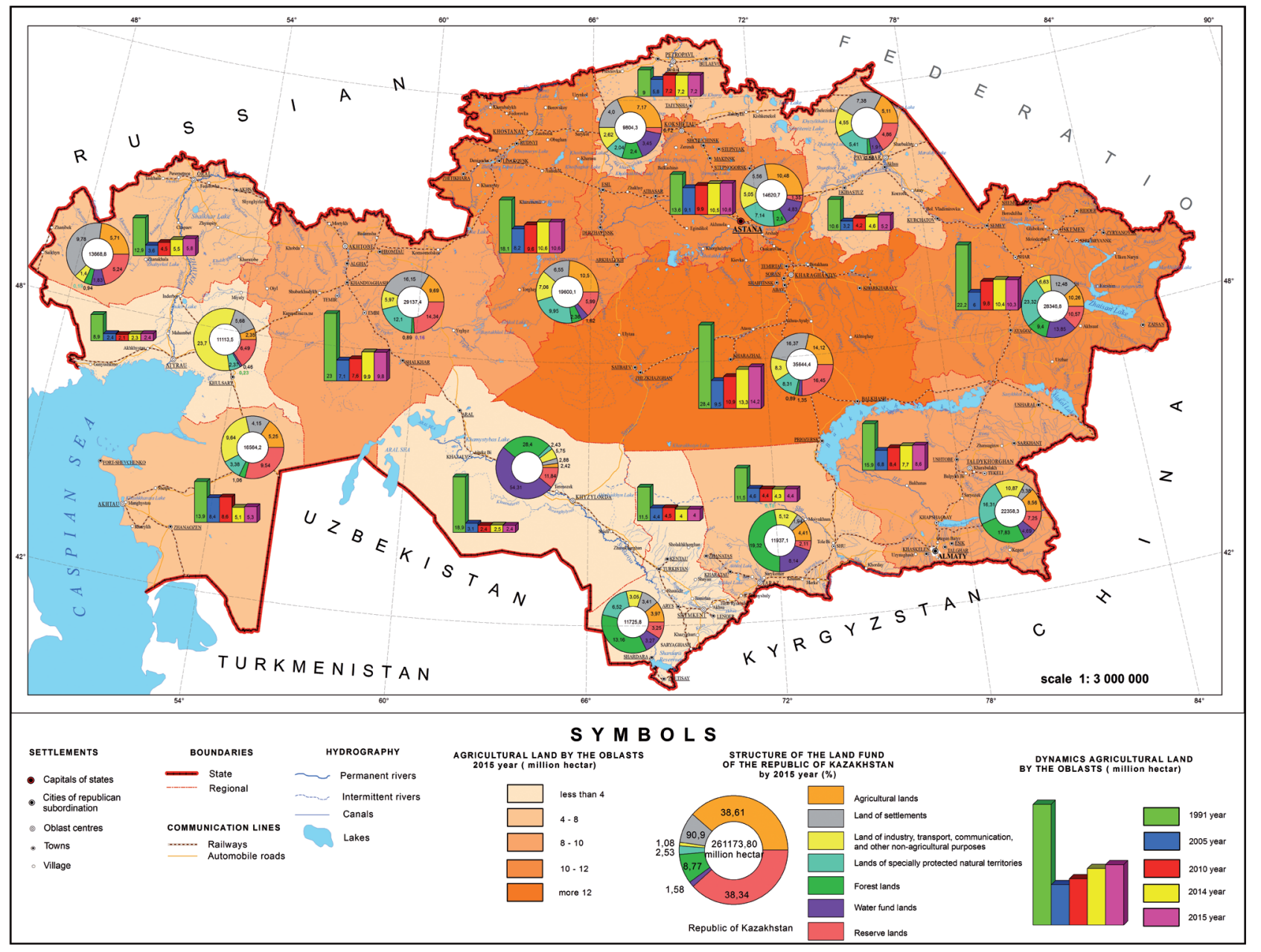

Fig. 1. Agricultural lands of the Republic of Kazakhstan. 
units in the agro-industrial complex. The most important result of the reforms was the formation of a multistructure economy in agriculture as one of the strategic directions of agrarian policy. However, any fundamental changes did not pass without serious consequences for the economy of the state. The destruction of multiyear interoblastal and inspectoral economic relations resulted in crisis in the agricultural sector. Analysis of the reforms in the agricultural sector shows that the formation and development of the multistructure economy was implemented in two stages: the first stage - the period of formation (from 1991 to 1999) and the second stage - the period of growth (since 2000). The first stage is characterized by structural rearrangement of the agro-industrial complex. Land reform was launched in 1991, and it was understood as being a change in land ownership relations, the elimination of monopoly of state property, and the transformation of collective and state farms into various organizational and legal formations [12-13].

There was the privatization of state land property, which was in the use of collective and state farms, and the redistribution of farmland in favor of peasant farms, private farms, and horticultural cooperative societies. As a result, at that time the economy reached the point where there were only 2,925 thousand hectares of farmland left in the state sector [14], while in the nonstate sector there were 341,100 hectares.

As a result of the reforms, capital investment into the agricultural sector practically stopped, production decreased, the living standards of the rural sector lowered sharply, and social tension in rural areas increased. In general, the sector incurred losses of 27.5 billion tenges, (\$435.1 million U.S.), profitability of crop products was minus $7.9 \%$, and livestock products were minus $41.4 \%$. Accounts payable of agricultural producers reached 121 billion tenges (\$1.9 billion). Because of the insolvency of the agricultural sector, the products of agricultural machinery enterprises, chemical, and other industries that are inseparably linked with the above-noted sector largely remained unclaimed.

The difficult situation in the agricultural sector in 1997 required measures to strengthen state support. In order to strengthen internal financial stability, since 1998 the process of financial rehabilitation and sanitation has begun in the republic through the application of bankruptcy procedures for insolvent agricultural enterprises.

In 1998-1999, in order to support agricultural producers, the government established tax privileges with a $10 \%$ VAT rate on a number of goods, and in July 1998 a patent taxation system for agricultural producers was introduced, which provided $80 \%$ reduction of payments to the budget. The patent system of taxation is a special taxation regime where the simplified tax is paid in advance. In support of the fact of payment of taxes, the tax inspection issues a document, which is called a patent.

\section{Analysis of the Main Indicators of the Agricultural} Sector in Kazakhstan

In Kazakhstan the agricultural sector is one of the most important branches of the economy, which allows for nearly complete food security, as well as exporting

Table 1. Companies specialized in the production of agricultural products in the ranking of the 500 largest companies in Kazakhstan.

\begin{tabular}{|c|c|c|c|}
\hline $\begin{array}{l}\text { Place in the } \\
\text { ranking - } 500\end{array}$ & Company & Sector & $\begin{array}{l}\text { Earned revenue, in million } \\
\text { tenges/ US dollars }\end{array}$ \\
\hline 38 & LLP "Holding” Alibi” & Production and sale of cereals & $\begin{array}{c}90373 \\
389.841\end{array}$ \\
\hline 116 & JSC "Holding Kazexportastyk" & Production of grain and oil crops & $\begin{array}{c}27864 \\
120.197\end{array}$ \\
\hline 273 & LLP "Medet-Holding" & Production and processing of grain & $\begin{array}{r}11630 \\
50.168 \\
\end{array}$ \\
\hline 279 & JSC “Alel-Agro" & $\begin{array}{c}\text { Commodity and breeding egg, poultry } \\
\text { meat }\end{array}$ & $\begin{array}{c}11630 \\
50.168\end{array}$ \\
\hline 314 & JSC "Ust-Kamenogorsk poultry factory" & Production of eggs and poultry meat & $\begin{array}{c}9784 \\
42.205\end{array}$ \\
\hline 321 & LLP Agrofirma TNK" & Grain production & $\begin{array}{c}9784 \\
42.205\end{array}$ \\
\hline 414 & JSC "Malt plant" Souffle Kazakhstan" & Malt production & $\begin{array}{c}6795 \\
29.311\end{array}$ \\
\hline 462 & LLP “Alatau-kus” & Poultry farm & $\begin{array}{c}5670 \\
24.458\end{array}$ \\
\hline 468 & LLP “Abi-Jer” & Plant growing & $\begin{array}{c}5610 \\
24.199\end{array}$ \\
\hline
\end{tabular}


significant amounts of agricultural products.

In 2010-2015 the share of agricultural sector in the GDP of Kazakhstan varies insignificantly and was about $7 \%$. At the same time, in 2010-2014 the share of the agricultural sector in total exports was relatively stable and averaged $17.4 \%$. In 2015 a significant increase in the share of agricultural sector in GDP was noted due to the sharp decline in exports in nominal terms as a consequence of the depreciation of the national currency.

As for the population of Kazakhstan, according to the results of 2015 , about $43 \%$ of the population lived in rural areas, and compared to 2010 when the ratio of rural population to the entire population of Kazakhstan was $45.5 \%$, this indicator tended to decrease. But in general, historically the share of the rural population varies between $40-45 \%$ of the country's total population.

A large part of the employed population is involved in the agricultural sector in Kazakhstan. But this number is less than in the sector of wholesale and retail trade (15\% of the economically active population) and industry $(13 \%)$.

In 2010 the number of employees in the agriculture sector was about 2.3 million people, which was $28 \%$ of the total employed population. A sharp decline of $30 \%$ can be observed in 2014, when the share of employed dropped to 1.6 million people, or $18.9 \%$ of the total economically active population. At the same time, the number of employees decreased almost twofold: from 193,000 in 2010 to 98,000 in 2015.

One of the reasons for the reduction in the number of agricultural employees is the fact that they earn the lowest wage among all sectors of the economy, which in 2015 in nominal terms was 70,869 tenges (\$319.6).

By the number of operating enterprises in the real sector, the agricultural sector had less than the manufacturing industry. On 1 January 2016, 8,089 enterprises producing agricultural products and 177,576 peasant (farm) farms operate in the industry.

According to National Business, in the ranking of the 500 largest companies, according to the level of income by the end of 2015, 9 companies specialized in the production of agricultural products (Table 1) [15].

The gross output of agricultural production of Kazakhstan continued to increase; its average annual value in the period 2010-2015 was about 2.2 trillion tenges ( $\$ 13$ billion). Structurally, the two main groups of the agricultural sector - crop production and livestock - account for an average of about 52.5\% and 47.2\%, respectively, of all agricultural products. The gross

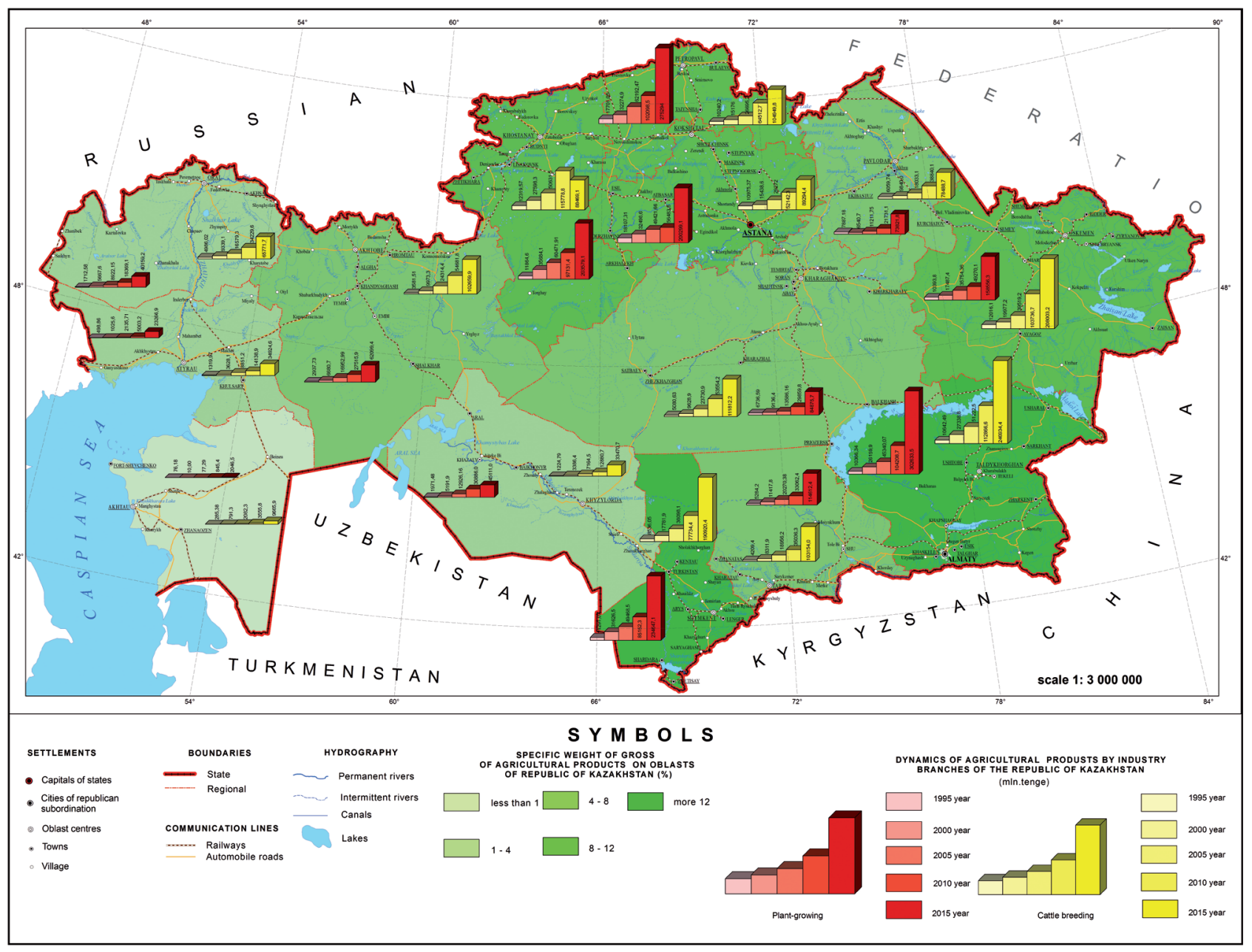

Fig. 2. Gross agricultural products of the republic of Kazakhstan. 


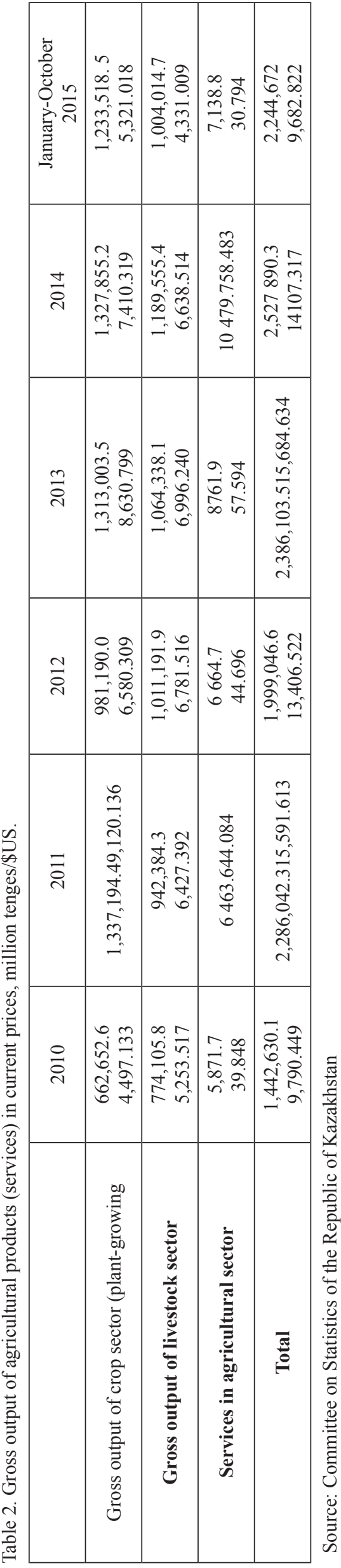

output of services rendered in the field of agriculture was extremely insignificant and was not more than $0.01 \%$ of gross output [15].

The increase in the gross output of agricultural production was noted in most oblasts of the republic since 1995. The largest ones were in Akmola, Kostanay, and North-Kazakhstan oblasts (Fig. 2) [16]. The high index of volume of agricultural production in these areas was formed due to the increase in the gross harvest of grain crops; its share in the gross output of the oblasts was $57-65 \%$.

In general, we can note the positive dynamics of the gross agricultural output of the republic. The volatility of the indicator is observed in 2011, in particular in the crop sector. This factor is due to a record volume of grain harvesting of 26.9 million tons, which is comparable to a similar volume in 1992 [15].

In 2014 the index of physical volume (IFI) of gross agricultural products (services) was $101.0 \%$. The decrease is due to the decrease in the production of crop products by $22.2 \%$ in comparison with 2013 . The formed IFI was largely affected by the decrease in gross grain harvest, which accounts for $18.9 \%$ of total agricultural output (services) (Table 2) [17].

In the livestock sector, the positive trend of production growth continued; on average, the increase in meat production over the past 5 years was $9.2 \%$, and the positive trend was in all types of livestock (except for pig breeding) [18].

In crop production, the cultivation of vegetables and melons, root plants, and tuber crops, as well as fodder and perennial crops, significantly increased. But the cultivation of tobacco decreased to the volume of 2011. In general, in 2010-2015 the cultivation of crops growing increased, but in this sector there was uneven growth because of climatic and technological factors [18].

The livestock sector in Kazakhstan demonstrated only positive dynamics of production growth. On average, the increase in livestock production was about $10.4 \%$; the positive trend was in all types of livestock, except for pig breeding. Sustainable rangeland management contains the linkages among vegetation dynamics management techniques and assessments that are based on ecological aspects and approaches for maintaining and enhancing the productivity of rangelands.

Consumption of fixed assets (FA) in value terms for 2010-2015, on average, was $17.5 \%$ of the acquisition cost. In recent years, a slight upward trend in this indicator has been noted. In general, for the analyzed period there was an increasing input of new fixed assets, its average annual value was 561 million tenges ( $\$ 3.06$ million). The exception was in 2014, when the introduction of new fixed assets decreased by $3.1 \%$.

In comparison with other branches of the real sector, the agricultural sector was characterized by a rather high coefficient of renewal of fixed assets; the average annual value was about $34 \%$. The decrease of the introduction of new fixed assets correlated with the decrease of the 
coefficient of renewal. At the same time, the increase in the coefficient of wear was on average $17.5 \%$, and the coefficient of liquidation fluctuated at the level of $0.5 \%$ for the period 2010-2015.

Analysis of the capital productivity of fixed assets of the agricultural sector showed a trend in the increase of this indicator. The observed fast increase in 2011 was an exception to the growing trend and is due to a record grain harvest and the resulting increase of gross agricultural output [5].

So in 2010, one tenge of the fixed asset created 1.01 tenge (\$147.35) of the final product, and in 2014 it was 1.32 tenge $(\$ 179.19)$. This fact indicates the effectiveness of the use of fixed assets.

\section{Investments in the Agrarian Sector}

The development of the country's agro-industrial complex is basically based on the investment activities of economic entities, since it is impossible to achieve sustainable growth in any industry without large-scale investments [8].

The investment process also affects the agricultural sector, and a significant number of processing enterprises face great problems in getting agricultural raw materials, so the implementation of long-term partnership programs for processors and farmers is necessary. The important function of these programs, primarily related to the technical and technological re-equipment of the agro-industrial complex and the creation of infrastructure, is the orientation of business entities to update and convert capital investments in accordance with long-term goals.

According to the World Bank, the second place in terms of efficiency in Kazakhstan, after oil production, is investments in the agricultural sector. With the growth of world prices for agricultural products, this industry is becoming more attractive. The program of agricultural reforms was launched by Kazakhstan at the time when the issue of joining the WTO [19] began to be discussed. To stimulate the development of domestic products, for farmers of processing enterprises, the state provides the following benefits: cheapening of fuels and lubricants, interest rates on loans in second-tier banks, leasing for the purchase of special equipment, and processing equipment [20].

Investments in the fixed capital of the agricultural sector are increasing. So, if in 2000 the volume of investments in the fixed capital of the sector was 8.2 billion tenges ( $\$ 577.7$ million) in 2010 , it was 83.5 billion tenges ( $\$ 566.5$ million), i.e., more than 10 times.

As the source of financing for investment in fixed assets, agricultural producers mainly use their own funds; their average annual share in the total volume of investments varies within $73 \%$. Bank lending in the agricultural sector is insignificant. The maximum volume of lending was observed in 2014 at 10 billion tenges (\$54.5 million, a specific share of $5.8 \%$ ), and the lowest volume was 5.5 billion tenges $(\$ 23.7$ million) in 2015 (a specific share of 3.3\%). The share of annual government subsidies is extremely low and tends to decrease. According to preliminary data of the Committee on Statistics of the Republic of Kazakhstan, in 2015, public funds allocated from the republican and local budgets were 175.3 million tenges (\$756.2 thousand), or $0.1 \%$ of the total volume of investments.

The volume of annual investments is increasing, with the exception of 2015, when the reduction was $3.6 \%$. In 2015 the agricultural sector received investment of about 167.1 billion tenges (\$751.8 million).

In comparison with other sectors of the republic, the agricultural sector in Kazakhstan is profitable, although in different periods the values of this indicator were uneven. At the same time, the profitability of the crop sector with an average annual value of about $30 \%$ is much higher than in the livestock sector, where profitability varies at $14 \%$ for the period from 2010 to 2014.

\section{Export Potential of Agricultural Products}

According to the analysis of Kazakhstan's geographical location, agricultural market capacities, and transport accessibility, it can be concluded that the countries of the Eurasian Economic Union (EAEU), the Commonwealth of Independent States (CIS), China, Iran, Afghanistan, and the United Arab Emirates (UAE) remain potential sales markets.

According to results of 2015, in terms of exported products the leaders were:

- Crop products: wheat, barley, corn, oilseeds.

- Livestock products: beef, pork, lamb, poultry.

According to livestock products, taking into account the internal security of domestic products, beef, pork, and lamb all have export potential. The largest volumes of exports of these products are observed in such countries as China, Russia, Iran, and the United Arab Emirates (Agricultural Development Program) [3].

In 2015 the share of the agricultural sector, together with forestry and fisheries, was $4.8 \%$ by the volume of exports, and in 2014 this indicator comprised 4.4\%.

The share of agricultural production in Kazakhstan's exports is small and by the end of January-October 2015 was $4.1 \%$. The volume of exports in quantitative terms for 10 months was more than $\$ 1.6$ billion - 24.9\% lower than for the same period in 2014.

Export of wheat is one of the main sources of foreign exchange earnings in the economy of the republic. Despite the fact that the country is in a zone of risky farming, and that grain harvesting can differ by more than $50 \%$ in different years, Kazakhstan is fully self-sufficient and exports at least $70 \%$ of the crop even in the most lean years. So for 10 months of 2015 Kazakhstan exported 397,942 tons of wheat.

The share of imports of agricultural products in the total segment is relatively small, and according to 
the results of January-October of this year is $10.9 \%$ of total republic import. The volume of imports of products in quantitative terms in 2015 was more than $\$ 2.8$ billion, which is $20.7 \%$ lower than for the same period in 2014. This trend is due to the abolition of the currency corridor and the transition to a freely floating exchange rate, and the decrease of consumer capacity of the population.

The main imports are meat, dairy products, vegetables, and fruit.

\section{Governmental Support}

In order to improve the rural economy, over the past 10 years state and sectoral programs supported by solid financial resources for the development and support of the agro-industrial complex (AIC) and the rural areas were adopted. In addition, in order to improve the system of state support of the agricultural sector, in 2006 the national holding company KazAgro was established, which includes: JSC National Company Food Contract Corporation, JSC Mal Onimderkorporatsiyatsy, JSC KazAgroFinance, JSC Agrarian Credit Corporation, JSC Fund for Financial Support of Agriculture, JSC KazAgroGarant, and JSC Kazagromarketing.

The holding's activities cover the implementation of state policy in the sphere of food security, crediting, insurance of agricultural enterprises, development of agricultural product markets, rural development, etc. [21].

In addition, the state supports the innovative development of agriculture, including its scientific, technical, and engineering support. For this purpose, the company KazAgroInnovation was established. It brought together research organizations of agricultural profile, including grain farming, livestock, food industry, forestry, agriculture, crop production, fisheries, agricultural mechanization, and agro-industrial complex economy. The combination of the scientific and production potential of agrarian science makes it possible to increase the efficiency of the creation and commercialization of new agrarian technologies, the transfer of promising foreign agrarian technologies, and their adaptation to local conditions.

Since 2013 the Agribusiness 2020 program has maintained a whole range of financial and non-financial mechanisms to support the agricultural sector [12, 22].

\section{Agro Ecological Situation}

Environmental problems related to agricultural activities include: 1) depletion and degradation of soil due to past state programs, erosion, secondary salinization, and flooding; 2) lack of water; 3) degradation of pastures caused by overgrazing and incomplete use/abandonment of more remote pastures; 4) soil contamination with chemicals; and 5) reduced biodiversity, for example, water biodiversity of the Aral Sea. Soil degradation is perceived as one of the main climate-related problems worldwide since it has large environmental and economical impacts, especially in agricultural areas. Many of these problems date back to the times of the Soviet Union. The others were aggravated by the decline in resources in the 1990s (for example, deforestation for fuel), and inappropriate regulation. However, the significant reduction in the sown area for crops and large-scale reduction in the use of fertilizers, as well as the reduced number of livestock, can be considered as positive consequences from the point of view of preserving ecology. Undoubtedly, as agricultural production increases, these problems will again become more acute [23-25].

Analyzing the distribution of agricultural lands by meliorative groups, it can be concluded that the category of agricultural lands includes the lands of highest quality in a meliorative relationship. Thus, as part of agricultural lands of this category of lands, the meliorative group with uncomplicated negative features, including, of course, lands suitable for agriculture, accounts for $28 \%$. The unit weight of other meliorative groups with negative features of a slight extent makes up about 24\%. Agricultural lands with negative features of a moderate and severe extent make up $48 \%$ of their total area. For comparison, in the whole country, the meliorative group with uncomplicated negative features makes up $19 \%$, with negative features of a slight extent $20 \%$, and of a moderate to severe extent more than $60 \%$.

In Kazakhstan, $24.9 \%$ of the total area of tillage has very low humus content (up to $2 \%$ ), $46.5 \%$ low (2-4\%), $23.9 \%$ average $(6.4 \%)$, and only $4.7 \%$ of soils have a high $(>6 \%$ ) humus content [3].

The category of agricultural lands contains $82 \%$ of all black soils, $61 \%$ of dark chestnut soils, and $40 \%$ of chestnut soils, which are the most valuable agriculturally.

In all the regions of Kazakhstan, soils have a steady downward trend in the content of humus, nutrients, and crop yield. According to the U. Uspanov Institute of Soil Science and Agricultural Chemistry, over the past 60 years humus content in the soil fell by one-third from its original content under non-irrigation, and by $60 \%$ under irrigation [26-27].

\section{Problems and Perspectives of Sustainable Development of the Agro Industrial Complex of Kazakhstan}

Despite some improvement in the situation in the agro-industrial complex over the past years, Kazakhstan remains a net importer of agricultural products, while the United States and a number of other developed countries are net exporters of food and maintain a high level of self-sufficiency. The level of self-sufficiency in the U.S. and France is $100 \%$, in Germany $93 \%$, in Italy $78 \%$, and in Japan - with its huge population and limited territory $-40 \%$ [28].

To date, the implementation of the agrarian policy of the state involves the use of a wide range of agricultural 
development tools, different in their economic characteristics. The application of these instruments in the Kazakhstan is distributed between the subjects of the state and quasi-state sectors responsible for the implementation of state tasks in the agrarian sphere, according to their functions.

One of the most important instruments is to give credit to the subjects of the agro-industrial complex on terms acceptable to them. In Kazakhstan, in order to provide agricultural enterprises with accessible credit resources, an extensive network of credit institutions for the agricultural sector has been established and is functioning, offering a variety of loan products. The largest are JSC KazAgroFinance and JSC Agrarian Credit Corporation.

To improve the process of agricultural production through the introduction of scientific developments, in Kazakhstan the institutes for the development of agrarian science have been established and are functioning, the largest one is JSC KazAgroInnovation.

The Ministry of Agriculture approved the Program for the Development of the Agro-Industrial Complex in the Republic of Kazakhstan for 2017-2021 for the further sustainable development of the agro-industrial complex and achievement of the tasks set by the head of state to ensure food security of the country, increase labor productivity, and export potential.

Despite the support measures taken by the state, Kazakh agriculture does not demonstrate sustainable development. According to statistical data for 20002015, there was a decrease (in comparison with the previous year) of the gross output of agricultural products (services) by $26.8 \%$, and its decrease by $17.8 \%$. At the same time, the share of agricultural output in GDP for this period decreased from $15.5 \%$ to $6.8 \%$ [2, 29-30].

In general, the current problems and weaknesses of the agricultural sector today include:

- Low level of investment activity in the agricultural sector; according to statistical agencies in 2015, the volume of investments in fixed assets in the agricultural sector was 139,626.9 million tenges (\$629.7 thousand), or $2.3 \%$ of total investments in fixed assets in all sectors [2].

- Small population of the republic, limiting the possibilities of increasing agricultural production.

- Low population density; in order to deliver agricultural products to a wide range of consumers it is necessary to overcome significant distances and, accordingly, transportation costs.

- Relatively low level of wages in the agricultural sector; according to statistical information at the end of 2015 , the average monthly salary of an employee in the agricultural sector was 58,011 tenges (\$261.6), which is almost 2 times lower than the average monthly salary for all other sectors; low wages, in turn, cause a shortage of qualified specialists in the agricultural sector.
- Lack of development of storage and transportation infrastructure for agricultural products; the problems are especially acute for grain producers in the years of a significant crop harvesting.

- Insufficiency of water resources to ensure stable agricultural production in a large part of the territory of Kazakhstan; the problem of water supply of domestic agricultural enterprises is especially aggravated in the dry periods.

- The small size of the bulk of domestic agricultural enterprises, which limits their ability to expand production and access to loans.

- Lack of access to oceans, limiting the possibilities of exporting domestic agricultural products to foreign countries.

- Low labor productivity in the agricultural sector, which is about $\$ 3,000$ per worker per year, while in the developed countries it is $\$ 50-70,000$.

Separately, the problem of non-use of agricultural land should be noted. So, according to the results of the inventory of 2012-2014, there were about 5 million hectares of unused land in the republic $[2,31]$.

Today, when oil prices are falling and the problems of the financial sector are increasing, Kazakhstan's agriculture is considered one of the most promising sectors of the economy, which can really become a locomotive on the path of economic development and give a new impetus to the strategy of diversifying the country's exports. As one of the priority directions of development of the republic's economy, agriculture has huge potential and large reserves. Various climatic conditions of Kazakhstan allow the growing of almost all cultures of the temperate heat zone and developing livestock.

\section{Conclusions}

Summing up the result of the above, it should be noted that for increases in sustainable development of agriculture there are both prerequisites and unused reserves.

The agriculture of Kazakhstan is an important sector for increasing employment and reducing poverty. Growth of the agricultural sector of Kazakhstan averaged $4.4 \%$ a year in 2001-2016. It is a high level of growth that surpasses the general growth of the economy in recent years in spite of the fact that it was below the average growth of GDP during the most recent part of the period and was uneven partly because of weather conditions.

According to official data, the agrarian sector produces only $4.7 \%$ of GDP of the country, and the labor productivity level in agriculture continues to remain among the lowest in comparison with other branches.

According to preliminary data of 2016 years, productivity of branch was a little more than $\$ 5,600$ on one occupied person that below an average indicator 
by the country for 3.5 times and much lower, than in developed countries. This means that increases in production in the domestic agrarian sector are reached for the most part at the expense of extensive factors, but not broad use of effective technologies as modern equipment and scientific methods.

For lack of advanced technologies of cultivation of soils and also in view of the shortage of qualitative sowing material, the modern harvest equipment, productivity level in Kazakhstan, even in comparison with the Economic Union (EAEU) remains, in general, low. Kazakh production often does not sustain the competition from, for example, Russian producers. In the market import food products began to prevail over Kazakh products, though positive tendencies appear in structure of external commodity turnover of the country. In 2016 the export of agricultural products occupied only $4.5 \%$, whereas the share of import was $11.3 \%$ [32].

Almost one-fifth of the working-age population works in agriculture, and therefore this sector is extremely important for food security and poverty reduction. Kazakhstan occupies one of the first places in the world in terms of the area of arable land per capita, producing grain almost one and a half times more than domestic demand. The natural potential of accessible pastures is estimated at 125 million hectares, or 11.3 hectares per head, which is almost 2 times higher than the standard. The amount of grazing land is one of the largest in the world and is equal to 181 million hectares. Currently, about $55 \%$ of the 2.4 million hectares that were irrigated during the Soviet era is used. Although areas planted with crops declined significantly in the 1990 s by 20 million hectares, with the withdrawal from the use of areas planted with low-quality forage grains the sown area increased by about 6 million hectares. Having about 188 million hectares of pasture, it uses only 80 million hectares, which is only $43 \%$ of the useful land. Of these, 27 million hectares are degraded, which, according to international experts of the United Nations, causes annual damage to the republic in the amount of up to \$1 billion.

One of the directions of sustainable development of agriculture, in our view, is the introduction of reserve lands into agricultural production and the provision of rural employment. In this regard, it is necessary to concentrate efforts on the development of livestock. This sub-sector of agriculture is the most labor-intensive, but its development will make it possible to create new jobs and enter into the circulation of reserve lands to create a fodder base.

In order to secure specialists in the countryside, it is necessary, along with the creation of jobs, to develop an appropriate state social program for housing construction. It is necessary to ensure the marketing infrastructure (roads, transport, markets, and purchase of goods, etc.), and renewal in rural areas at the expense of budget allocations for educational, medical, cultural, and sports facilities. To address these issues, it is advisable to develop a program to build housing for young professionals in rural areas and improve the living conditions of rural residents until 2020, by analogy with the state housing program for 2005-2007 and 2008-2010.

It is necessary to place industrial production in rural settlements, taking into account specialization, subsidiary crafts, and handicrafts; in a rural area to apply a special regime of taxation and other benefits.

In the agricultural sector of Kazakhstan it is necessary to attract foreign agricultural companies of the full cycle. Particular attention should be given to the issues of rational use of the production and export potential of the agricultural sector. One of the most important areas of export policy is the development of new markets.

In summary, it can be said that the programs and the main measures included in them, as well as the republic's targeted programs for sustainable development of agriculture, represent in aggregate a set of interrelated measures aimed at solving the most important current and long-term goals and tasks that ensure the country's food independence. The socio-economic development of the agro-industrial complex on the basis of its modernization and transition to an innovative model of functioning in the context of expanding world economic ties leads to sustainable development of rural areas and positively affects the country's macroeconomic indicators.

\section{Acknowledgements}

The authors are grateful to the Committee of Land Resource Management and the non-profit joint stock company State Corporation Government for Citizens for providing the summary analytical report.

\section{References}

1. Sustainable development of agriculture and rural territories: Foreign experience and problems of Russia. M, 229, 2005.

2. Promoting sustainable agriculture and rural development Rome: FAO, 1996.

3. Sustainable development of rural territories: Questions of strategy and tactics. M, 19-20-188, 2004.

4. Our general future: report of the international commission for the environment and development. - M.: Progress. 20, 1989.

5. RASTOPCHINA YU. L., KOVALYOVA E.I. Indicators of sustainable development as tool of assessment of development of agriculture and rural territories//Young scientist. 11, 195, 2012.

6. Sustainable Development Knowledge Platform. Outcome Document - Open Working Group on Sustainable Development Goals // http://sustainabledevelopment. un.org/focussdgs.html

7. Transition Concept of Kazakhstan to Sustainable Development for 2007-2024. / NP. Kazakhstanskaya 
Pravda, from November 16-18, 249 (25,220), 251 (25,222), 2006.

8. TOKBERGENOVA A.A., KAIROVA SH.G., KIYASSOVA L.Sh. Analysis of modern state of land resources of the Republic of Kazakhstan. KazNU Bulletin. Ecology series. 2/2 (44), 767, 2015.

9. Summary analytical report on a state and use of the lands of the Republic of Kazakhstan for 2015. Astana, 125, 2016.

10. TOKBERGENOVA A.A., NYUSSUPOVA G.N., KAIROVA SH.G., KIYASSOVA L.Sh. Causes and Impacts of Land Degradation and Desrtification: Case Study of Republic of Kazakhstan. GEOMED $20164^{\text {th }}$ International Geography Symposium. Kemer, Antalya, TURKEY, 158, 2016.

11. OMARBEKOVA A.D, PENTAYEV T.P., IGEMBAYEVA A.K., ABAYEVA K.T. Analysis of Prospects for Sustainable Land use (Lands of Agricultural Designation) in the Republic of Kazakhstan in the Context of the Development of Alternative Energy. International Journal of Energy Economics and Policy. 7 (2), 337, 2017.

12. Stages of the development of agro-industrial complex of the Republic of Kazakhstan http://kazakh-zerno.kz.

13. AKIMBEKOVA G., HORSK E., YEGIZBAYEVA G. Evaluation of the Development of Various Forms of Agriculture Cooperation in the Republic of Kazakhstan. Visegrad Journal on Bioeconomy and Sustainable Development. DOI: 10.1515/vjbsd-2017-0007. 39, 2017.

14. TOKBERGENOVA A.A., KIYASSOVA L.SH. The qualitative state of the land resources of the Republic of Kazakhstan. Vestnik of KazNTU 3, 12, 2015.

15. SHINKEEVA G. Analysis of agriculture of the Republic of Kazakhstan, JSC RFCA Rating Agency, 2016.

16. The official website of the Committee on Statistics of the Republic of Kazakhstan. Available in: http://www.stat.gov. $\mathrm{kz}$

17. Review of agriculture of the Republic of Kazakhstan. Analytical service of the RFCA Rating Agency. - Almaty, 2015.

18. Investments in the agrarian sector https://articlekz.com/ article/10741).

19. AKHMETOVA K.A. Infrastructure of agricultural sector of Kazakhstan: status and problems. // Problems of agricultural market. Theoretical magazine. Almaty. 3, 2008.
20. World Bank Group - International Development, Poverty, \& Sustainability; www.worldbank.org/.

21. Agriculture in Kazakhstan http://www.kazportal.kz/ selskoe-hozyaystvo-v-kazahstane

22. ORYNBASSAROVA Y.D Investment Providing Innovative Projects in Agro-Industrial Complex of Kazakhstan. DOI 10.12851/EESJ201404ART27

23. TOKBERGENOVA A.A., KIYASSOVA L.Sh. The basis of ways of rational use of agricultural land in Kazakhstan. KazNU Bulletin. Ecology series. $2 / 2$ (44), 747, 2015.

24. NYUSSUPOVA G.N., TOKBERGENOVA A.A. The problems and ways of improving the farming systems in the Republic of Kazakhstan. Vestnik of KazNTU 3, 7, 2015.

25. GLAZOVSKYI N.F. Sustainable agriculture and rural areas. Foreign experience and the Russian problems / N.F. Glazovskyi, N.F. Gordeev, G.V. Sdasyuk. - M.: Association of scientific editions KMK. 615, 2005.

26. NYUSSUPOVA G.N., TOKBERGENOVA A.A., KAIROVA SH.G., ARSLAN M. Mechanisms of the formation of ecologically oriented agricultural land use in Kazakhstan // Oxidation Communication. - Bulgaria. - 2, 886-899. (892), 2015.

27. LAISKHANOV SH.U., OTAROV A., SAVIN I.Y., TANIRBERGENOV S.I., MAMUTOV ZH.U., DUISEKOV S.N., ZHOGOLEV A. Dynamics of Soil Salinity in Irrigation Areas in South Kazakhstan. Polish Journal of Environmental Studies. 25 (6), 2469, 2016.

28. ZHANGIROVA R.N. Problems of the sustainable development of the agrarian sector. Bulletin of KazNPU http://articlekz.com/article/10741.

29. ZAGLYADOVA M.KH. Realization of socio-economic policy in relation to rural areas // Russian Entrepreneurship. 9, 90, 2013.

30. JSC "KazAgroInnovation", 2010. Strategy of the Extension System Developemnt in the Sphere of Agriculture Industry Complex per 2010-2014. Astana: KazAgroInnovation. http://kai.gov.kz/kz

31. ELESHOV R.E. The modern concept of development of branches of agriculture//the Perspective directions of stabilization and development of agro-industrial complex of Kazakhstan in modern conditions: sb. scientific works. Uralsk., 15, 2004.

32. Information portal zakon.kz/http://www.zakon.kz/. 
